\title{
PENGARUH VALUE ADDED INTELLECTUAL CAPITAL (VAIC) TERHADAP KINERJA KEUANGAN BANK UMUM SYARIAH YANG TERDAFTAR DI BANK INDONESIA PERIODE 2015 - 2019
}

\author{
Viras Alti Pidola \\ Julina \\ Sitti Rahmah \\ Universitas Islam Negeri Sultan Syarif Kasim Riau \\ E-mail: Virasaltipidola1402@gmail.com
}

\begin{abstract}
Abstrak
Intellectual Capital adalah komponen yang dimiliki oleh suatu perusahaan dalam mengukur nilai sumber daya manusia didalamnya yang memberikan keunggulan bersaing. Intellectual Capital perusahaan tidak dapat diukur langsung tetapi mengajukan suatu ukuran untuk menilai efisiensi dari nilai tambah sebagai hasil dari kemampuan intelektual perusahaan. Penelitian ini adalah penelitian dengan menggunakan data sekunder dengan metode penelitian kuantitatif. Teknik pengumpulan data melalui dokumentasi berupa pencatatan laporan keuangan pada Bank Umum Syariah Periode 2015-2019 yang dipilih menggunakan metode purposive sampling dengan pengolahan data menggunakan program SmartPLS 3.0. Teknik analisis data yang digunakan adalah metode Partial Least Square (PLS). Hasil penelitian yang di dapat dari program PLS adalah Intellectual Capital mempunyai pengaruh terhadap Return On Asset (ROA), Net Imbalan (NI), Beban Operasional terhadap Pendapatan Operasional (BOPO), dan Finance to Deposit Ratio (FDR) tetapi Intellectual Capital tidak memiliki pengaruh terhadap Capital Adequancy Ratio (CAR) dan terhadap Zakat Performing Ratio (ZPR).
\end{abstract}

Kata Kunci: VAIC, ROA, NI, BOPO, CAR, FDR, ZPR

\begin{abstract}
Intellectual Capital is a component owned by a company in measuring the value of human resources in it that provides competitive advantage. The company's intellectual capital cannot be measured directly but proposes a measure to assess the efficiency of added value as a result of the company's intellectual ability. This research was conducted by using secondary data with quantitative research methods. The data was collected through documentation in the form of financial statements recordings at Islamic Commercial Banks for the 2015-2019 period
\end{abstract}


that were selected using the purposive sampling method. The data were processed by using the SmartPLS 3.0 program. The processed data were analyzed by using the Partial Least Square (PLS) method. Based on the results of the research, it is obtained from the PLS program that Intellectual Capital has an influence on Return On Assets (ROA), Net Returns (NI), Operating Expenses on Operating Income (BOPO), and Finance to Deposit Ratio (FDR). but Intellectual Capital has no effect on the Capital Adequacy Ratio (CAR) and on the Zakat Performing Ratio (ZPR). This may be due to several influencing external factors.

Keywords: VAIC, ROA, NI, BOPO, CAR, FDR, ZPR

\section{Pendahuluan}

Kinerja bank merupakan bagian dari kinerja bank secara keseluruhan. Kinerja bank secara keseluruhan menggambarkan kinerja bank dalam kegiatan operasionalnya, baik dari segi keuangan, pemasaran, penghimpunan dan penyaluran dana, teknologi maupun sumber daya manusia. Kinerja keuangan bank menggambarkan keadaan keuangan bank dalam kurun waktu tertentu, baik dari segi penggalangan dana maupun dari segi penyaluran dana, biasanya diukur dengan menggunakan indikator kecukupan modal, likuiditas dan profitabilitas bank. ${ }^{1}$

Ketentuan mengenai perbankan syariah tertuang dalam Undang-Undang Nomor 21 Tahun 2008 tentang Perbankan Syariah. Bank Syariah adalah bank yang menjalankan usahanya berdasarkan prinsip syariah. Perkembangan terkini mengenai pertumbuhan bank syariah di Indonesia dapat dilihat pada statistik Otoritas Jasa Keuangan Januari 2020. Ada 14 bank umum syariah di seluruh Indonesia.

Pengukuran tepat modal intelektual di perusahaan tidak dapat ditentukan dengan pasti. Hal ini berbeda dengan peningkatan pengakuan modal intelektual dalam mempromosikan nilai bisnis dan keunggulan kompetitif. Adanya kesulitan dalam mengukur modal intelektual secara langsung membuat keberadaannya di perusahaan sulit untuk ditentukan. ${ }^{2}$ Pulic, seperti dikutip Halim, mengusulkan

\footnotetext{
${ }^{1}$ Jumingan, Analisis Laporan Keuangan ( Jakarta: PT Bumi Aksara, 2006), hal. 239

${ }^{2}$ Halim Adi Gunawan, Pengukuran, Pengakuan dan Pengungkapan Intellectual capital Terhadap Penilaian Kinerja Perusahaan (Jurnal Ilmiah Akuntansi, Vol. 1, No.3. 2012), hal. 41
} 
metode pengukuran modal intelektual secara tidak langsung dengan ukuran menilai efisiensi nilai tambah berdasarkan kemampuan intelektual perusahaan, yaitu menggunakan Value Added Intellectual Coefficient (VAIC). ${ }^{3}$

Metode pengukuran ini tidak mengukur modal intelektual perusahaan secara langsung, tetapi menyarankan suatu ukuran untuk mengevaluasi efisiensi nilai tambah berdasarkan kemampuan intelektual perusahaan (Value AddedIntellectual Coefficient-VAIC). Komponen utama VAIC dapat dilihat dari sumber daya perusahaan, yaitu modal fisik (VACA - modal nilai tambah terapan), modal manusia (VAHU - modal manusia dengan nilai tambah, dan modal struktural (STVA - modal struktural).

Tujuan utama ekonomi pengetahuan adalah untuk menciptakan nilai. Agar dapat menambah nilai, diperlukan ukuran yang tepat dari modal fisik (yaitu sarana finansial) dan potensi intelektual (diwakili oleh karyawan dengan segala potensi dan kemampuan yang melekat) diperlukan. Kemampuan intelektual (yang kemudian disebut VAIC) menunjukkan bagaimana kedua sumber daya (modal fisik dan modal intelektual) telah digunakan secara efektif oleh perusahaan untuk meningkatkan kinerja keuangan perusahaan.

Adapun rumusan masalah dalam penelitian ini adalah ; (1) Apakah Value added Intellectual Capital berpengaruh terhadap Return On Asset (ROA)? (2) Apakah Value added Intellectual Capital berpengaruh terhadap Net Imbalan (NI)? (3) Apakah Value added Intellectual Capital berpengaruh terhadap Operating Expense to Operating Income (BOPO)? (4) Apakah Value added Intellectual Capital berpengaruh terhadap Capital Adequacy Ratio (CAR)? (5) Apakah Value added Intellectual Capital berpengaruh terhadap Finance to Deposit Ratio (FDR)? (6) Apakah Value added Intellectual Capital berpengaruh terhadap Zakat Performing Ratio (ZPR)?

Tujuan yang ingin dicapai dari permasalahan diatas adalah; (1) Menganalisis pengaruh Value added Intellectual Capital terhadap Return On Asset (ROA)? (2) Menganalisis pengaruh Value added Intellectual Capital terhadap Net Imbalan (NI)? (3) Menganalisis pengaruh Value added Intellectual Capital terhadap Operating Expense to Operating Income (BOPO)? (4) Menganalisis pengaruh Value added Intellectual Capital terhadap Capital Adequacy Ratio (CAR)? (5) Menganalisis pengaruh Value added Intellectual Capital terhadap Finance to

${ }^{3}$ Werner R Murhadi, Analisis Laporan Keuangan Proyeksi dan Valuasi Saham (Jakarta: Salemba Empat, 2015), hal. 24. 
Deposit Ratio (FDR)? (6) Menganalisis pengaruh Value added Intellectual Capital terhadap Zakat Performing Ratio (ZPR)?

Sullivan mendefinisikan modal intelektual sebagai nilai tambah dari bakat manusia yang ditransformasikan oleh sumber daya yang disediakan oleh struktur perusahaan. Dalam literatur pengetahuan, istilah ini terkait erat dengan topik seperti inovasi, yang merupakan cara lain untuk mengatakan bahwa modal intelektual sulit dipahami oleh banyak organisasi. Tidak seperti modal finansial, yang dapat dikelola secara langsung atas dasar laba, modal intelektual membutuhkan metode tidak langsung untuk menciptakan nilai dan menghasilkan keuntungan. ${ }^{4}$

Value added intellectual coefficient (VAIC) yang dikembangkan oleh publik dalam pengukuran intellectual capital. Metode yang ditemukan oleh public ini, bertujuan untuk menyajikan informasi tentang value creatin efficeincy dari aset berwujud (tangible assets) dan aset tidak berwujud (intangible asset) yang dimiliki perusahaan. ${ }^{5}$ Dari sekian banyak metode pengukuran IC yang dikembangkan oleh beberapa peneliti, penelitian ini memilih metode pengukuran yang dikembangkan oleh Pulic yaitu Value Added Intellectual Coefficient (VAIC). Metode VAIC (Value Added Intellectual Coefficient) dikembangkan oleh publik pada tahun 1997 dan dimaksudkan untuk memberikan informasi mengenai efisiensi nilai tambah dari property, plant and equipment dan intangible asset perusahaan. VAIC adalah alat yang digunakan untuk mengukur kinerja modal intelektual perusahaan. Pendekatan ini relatif sederhana dan sangat mungkin dilakukan karena adanya pembuatan akun dalam laporan keuangan tahunan perusahaan (neraca, laba rugi). ${ }^{6}$

VAIC mengindikasikan kemampuan intelektual organisasi yang dapat juga dianggap sebagai BPI (Business Performance Indicator). VAIC merupakan penjumlahan dari 3 komponen sebelumnya, yaitu : VACA, VAHU dan STVA. Keuntungan dari metode VAIC adalah data yang dibutuhkan dapat diperoleh

\footnotetext{
${ }^{4}$ Ihyaul Ulum, Intellectual Capital (Yogyakarta: Graha Ilmu, 2009), hal. 94

${ }^{5}$ Khoe Yao Tung, Memahami Knowledge Management (Jakarta Barat: Indeks, 2018), hal.16.

${ }^{6}$ Ihyaul Ulum, iB-VAIC: Model Pengukuran Kinerja Intellectual Capital Perbankan

Syariah di Indonesia (dalam Jurnal Inferensi 7 (1): 183-204, 2013), hal. 8-9.
} 
dengan relatif mudah dari berbagai sumber dan jenis perusahaan. Data yang diperlukan untuk menghitung berbagai metrik tersebut adalah angka keuangan standar yang umumnya diperoleh dari laporan keuangan perusahaan.

Return On Asset (ROA) merupakan perbandingan antara laba sebelum pajak dengan total asset dalam suatu periode. ${ }^{7}$ Rasio ini digunakan untuk mengukur kemampuan manajemen bank dalam menghasilkan keuntungan total. Semakin tinggi ROA bank, semakin tinggi keuntungan yang diperoleh bank dan semakin baik posisi bank sehubungan dengan penggunaan aset.

NI (Net Imbalan) adalah rasio yang digunakan untuk menentukan kemampuan memperoleh aset untuk menghasilkan laba dengan membandingkan pendapatan operasi dikurangi manfaat dan bonus dengan pendapatan rata-rata. Semakin tinggi NI, maka semakin efektif bank menempatkan aset produktif berupa pinjaman.

Beban Operasional terhadap Pendapatan Operasional (BOPO) adalah rasio perbandingan antara biaya operasional dengan pendapatan operasional. Beban operasi terhadap laba operasi (BOPO) adalah perbandingan antara beban operasi dan laba operasi. Semakin rendah tingkat BOPO, semakin baik kinerja manajemen bank tersebut.

Capital Adequacy Ratio (CAR) merupakan alat untuk mengukur kemampuan suatu bank dalam mempertahankan modalnya dan megukur kemampuan manajemen dalam mengontrol mengidentifikasi serta mengawasi resiko-resiko yang nantinya timbul pada besarnya modal bank. Rasio ini dapat menunjukkan sejauh mana penurunan asset Bank yang masih ditutup oleh equity Bank yang tersedia.

Finance to Deposit Ratio (FDR) adalah rasio pembiayaan terhadap dana pihak ketiga yang diterima oleh bank. Rasio ini digunakan untuk mengukur tingkat likuiditas. Rasio yang tinggi menunjukkan bahwa suatu bank meminjamkan seluruh dananya atau tidak likuid. Sebaliknya, rasio yang rendah menunjukkan bank yang likuid.

Zakat Performing Ratio (ZPR) digunakan dalam penelitian ini untuk mengukur besarnya kontribusi zakat perusahaan yang dikeluarkan oleh Perbankan Syariah.

${ }^{7}$ Martono dan Agus Harjiko, Manajemen Keuangan (Yogyakarta: Ekonosia,2005), hal. 60 


\section{Metode}

Analisis data dilakukan dengan metode Partial Least Square (PLS). PLS adalah metode penyelesaian Structural Equation Modelling (SEM) yang dalam hal ini (sesuai tujuan penelitian) lebih tepat dibandingkan dengan teknik-teknik SEM lainnya. Jumlah sampel yang kecil, potensi distribusi variabel tidak normal, dan penggunaan indikator formatif dan refleksif membuat PLS lebih sesuai untuk dipilih dibandingkan dengan misalnya, maximum likelihood SEM. Pemilihan metode PLS didasarkan pada pertimbangan bahwa dalam penelitian ini terdapat dua variabel laten yang dibentuk dengan indikator formatif, dan bukan refleksif. Model refleksif mengasumsikan bahwa konstruk atau variabel laten mempengaruhi indikator, dimana arah hubungan kausalitas dari konstruk ke indikator atau manifest. Ghozali menyatakan bahwa model formatif mengasumsikan bahwa indikator- indikator mempengaruhi konstruk, dimana arah hubungan kausalias dari indikator ke konstruk. ${ }^{8}$

\section{Hasil Dan Pembahasan}

\section{Analisis Deskriptif}

Tabel 1. Statistik Deskriptif

\begin{tabular}{|c|c|c|c|c|c|c|c|c|c|}
\hline & $\mathrm{Ka}$ & Nowing & Hexn & Melix & Mn & Ner & Endar Devil. & Avess furmis & Sineres \\
\hline ISte & 1 & 0 & $48 ?$ & $2 \pi$ & 14 & $325 \pi$ & 25 & 2050 & stat \\
\hline ath & 2 & 0 & cas & Dew & का & ath & $2 A 4$ & net & 323 \\
\hline$J \cos$. & 3 & 9 & 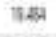 & $7 x$ & IIII & $\$ 200$ & 6213 & 190 & 1 표 \\
\hline $2 \mathrm{H}$ & 4 & 3 & 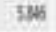 & sim & an & प्रयू & 1 & 43 & 23 \\
\hline NOPO & 3 & $\theta$ & $\operatorname{sen}$ & $Y \in(x)$ & 11260 & $2 \pi m$ & 200 & 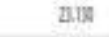 & $4 x$ \\
\hline 108 & 6 & 0 & $5 \pi \pi$ & wes & 72 & 10338 & ats & Was & Ach \\
\hline 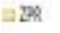 & 7 & 0 & 029 & 0214 & 000 & 0,12 & 0.16 & $\sin 2$ & dSA \\
\hline
\end{tabular}

Pada tabel 1 dapat disimpulkan bahwa bahwa rata-rata intellectual capital adalah sebesar 4,157 dengan standar deviasi sebesar 5,721. Nilai standar deviasi lebih besar dibandingkan nilai rata-rata. Ini menunjukkan terjadinya variasi atau perbedaan yang tinggi antara intellectual capital terhadap nilai rata-ratanya. VAIC mengindikasikan kemampuan intelektual organisasi yang dapat juga dianggap sebagai BPI (Business Performance Indicator) semakin tinggi nilainya maka semakin bagus nilai kemampuan intelektual organisasi.

8 Imam Ghozali, Structural Equation Modeling Metode Alternatif dengan Partial Least Square (Semarang: Badan Penerbit Universitas DIponegoro . 2014), hal.20 
Rata-rata Return On Asset (ROA) adalah sebesar 0,053 dengan standar deviasi sebesar 2,414. Nilai standar deviasi lebih besar dibandingkan nilai ratarata menunjukkan terjadinya variasi atau perbedaan yang cukup besar antara Return On Asset (ROA) terhadap nilai rata-ratanya. Return On Assets (ROA) merupakan rasio profitabilitas yang mengukur jumlah laba yang diperoleh dari tiap rupiah aset yang dimiliki oleh perusahaan. ROA menunjukkan kemampuan manajemen bank dalam melakukan efisiensi penggunaan total aset untuk operasional perusahaan. Semakin tinggi ROA suatu bank semakin tinggi pula keuntungan yang dicapai bank tersebut dan semakin baik posisi perusahaan dari segi penggunaan aset.

Rata-rata Capital Adequancy Ratio (CAR) adalah sebesar 19,484 dengan standar deviasi sebesar 6,213. Nilai standar deviasi lebih kecil dibandingkan nilai rata-rata menunjukkan terjadinya variasi atau perbedaan yang kecil antara Capital Adequancy Ratio (CAR) terhadap nilai rata-ratanya. CAR adalah rasio yang memperlihatkan seberapa besar jumlah seluruh aktiva bank yang mengandung risiko (kredit, penyertaan, surat berharga, tagihan pada bank lain) ikut dibiayai dari modal sendiri disamping memperoleh dana-dana dari sumber-sumber di luar bank.

Rata-rata Net Imbalan (NI) adalah sebesar 5,846 dengan standar deviasi sebesar 1,868. Nilai standar deviasi lebih kecil dibandingkan nilai rata-rata menunjukkan terjadinya variasi atau perbedaan yang kecil antara Net Imbalan (NI) terhadap nilai rata-ratanya. Net Imbalan (NI) digunakan untuk mengukur kemampuan manajemen bank dalam mengelola aktiva produktifnya untuk menghasilkan pendapatan bunga bersih.

Rata-rata Operating Expense to Operating Income (BOPO) adalah sebesar 98,893 dengan standar deviasi sebesar 20,873. Nilai standar deviasi lebih kecil dibandingkan nilai rata-rata menunjukkan terjadinya variasi atau perbedaan yang kecil antara Operating Expense to Operating Income (BOPO) terhadap nilai rata-ratanya. Operating Expense to Operating Income (BOPO) merupakan perbandingan antara biaya operasional dengan pendapatan operasional. Semakin rendah tingkat rasio BOPO berarti semakin baik kinerja manajemen bank tersebut. Perusahaan yang memiliki kemampuan intelektual yang lebih tinggi akan dapat mengelola biayanya dengan lebih efisien. BOPO merupakan rasio yang menunjukkan efisiensi kinerja operasional bank. Semakin kecil BOPO maka bank dinilai memiliki efisiensi kinerja operasional yang semakin baik. Nilai rasio BOPO yang rendah berarti bank dapat menutup biaya operasional dengan pendapatan 
operasionalnya sehingga untuk mencapai efisiensi operasional, bank syari'ah harus dapat meningkatkan pendapatan operasionalnya.

Rata-rata Finance to Deposit Ratio (FDR) adalah sebesar 86,971 dengan standar deviasi sebesar 8,137. Nilai standar deviasi lebih kecil dibandingkan nilai rata-rata menunjukkan terjadinya variasi atau perbedaan yang kecil antara Finance to Deposit Ratio (FDR) terhadap nilai rata-ratanya. Rasio ini digunakan untuk mengukur tingkat likuiditas. Rasio yang tinggi menunjukkan bahwa suatu bank meminjamkan seluruh dananya atau tidak likuid. Sebaliknya, rasio yang rendah menunjukkan bank yang likuid.

Rata-rata Zakat Performance Ratio (ZPR) adalah sebesar 0,210 dengan standar deviasi sebesar 0,183. Nilai standar deviasi lebih kecil dibandingkan nilai rata-rata menunjukkan terjadinya variasi atau perbedaan yang kecil antara Zakat Performance Ratio (ZPR) terhadap nilai rata-ratanya. Zakat Performance Ratio (ZPR) Zakat harus menjadi salah satu tujuan akuntansi syariah terlebih zakat merupakan salah satu perintah dalam Islam. Oleh karena itu, kinerja bank syariah harus didasarkan pada zakat yang dibayarkan oleh Bank untuk menggantikan indikator kinerja konvensional yaitu rasio laba per saham (earning per share). Kekayaan bank harus didasarkan pada aktiva bersih (net asset) dari pada laba bersih (net profit) yang ditekankan oleh metode konvensional.

\section{Analisis Inferensial dengan Partial Least Square (PLS)}

\section{Convergent Validity}

Convergent Validity atau validitas konvergen terpenuhi jika terdapat interkorelasi yang cukup antar variabel-variabel (indikator) yang digunakan untuk mengukur konstruk yang sama. Dimana nilai dari outer loading > 0.50, maka faktor tersebut memiliki nilai convergent validity yang baik. Berikut akan dipaparkan hasil dari perhitungan yang telah dilakukan menggunakan SmartPLS 3.0

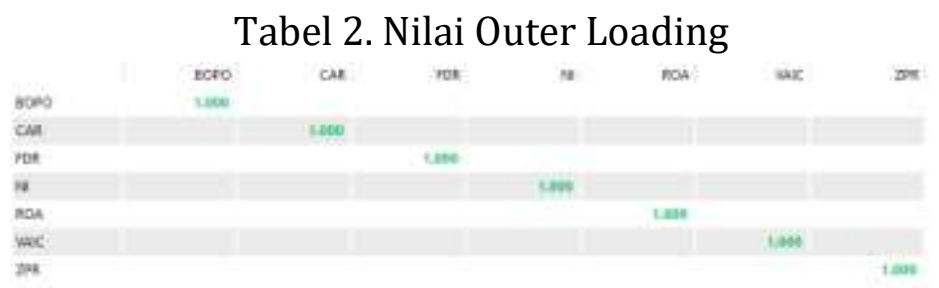

Tabel 2 menunjukkan bahwa nilai loading factor untuk tiap pernyataan lebih besar dari 0,5. Berarti indikator yang dipergunakan dalam penelitian ini adalah valid atau telah memenuhi convergent validity. 
Discriminant Validity

Evaluasi ini merupakan nilai akar kuadrat dari AVE dan harus memiliki nilai lebih besar daripada nilai korelasi antar variabel laten. Dapat juga diukur dengan melihat nilai cross loading pengukuran dengan konstruk. Jika korelasi konstruk dengan item pengukuran lebih besar daripada ukuran konstruk lainnya, maka menujukkan bahwa konstruk laten memprediksi ukuran pada blok mereka lebih baik daripada ukuran pada blok lainnya. Direkomendasikan nilai pengukuran harus lebih besar dari 0.50 .

Tabel 3. Nilai Average Variance Extracted ( AVE )

\begin{tabular}{|c|c|c|c|c|}
\hline & Cronbach's Alpha & tho $A$ & Composite Refability & Average lariance Extracted (AVE) \\
\hline$B O P O$ & 1000 & 1.000 & 1000 & 1.000 \\
\hline CAR & 1.000 & 1.000 & 1.000 & 1000 \\
\hline FDR & 1000 & 1.000 & 1000 & 1.000 \\
\hline NI & 1000 & 1.000 & 1000 & 1.500 \\
\hline ROA & 1000 & 1.000 & 1000 & 1000 \\
\hline VAK & 1000 & 1.000 & 1000 & 1000 \\
\hline$Z P R$ & 1.000 & 1.000 & 1,000 & 1.000 \\
\hline
\end{tabular}

Tabel 3 menunjukkan bahwa nilai AVE $>0,5$, hal ini menunjukkan bahwa semua variabel dalam model yang diestimasi memenuhi criteria discriminant validity.

Composite reliability

Composite reliability digunakan untuk menguji reliabilitas suatu variabel. Selain melihat nilai composite reliability, evaluasi ini juga dapat dilihat dari cronbach's alpha. Suatu variabel dianggap reliabel jika nilai composite reliability maupun cronbach's alpha lebih dari 0,7.

Tabel 4. Nilai Composite Reliability 


\begin{tabular}{|c|c|c|c|c|}
\hline & Cronbach's Alpha & tho $A$ & Composite Relability & Average Variance Extracted (AVI) \\
\hline$B O P O$ & 1000 & 1.000 & 1000 & 1.000 \\
\hline CAR & 1.000 & 1.000 & 1.000 & 1000 \\
\hline FDR & 1000 & 1.000 & 1960 & 1000 \\
\hline NI & 1000 & 1.000 & 1000 & 1000 \\
\hline ROA & 1.000 & 1.000 & 1.000 & 1.000 \\
\hline VAC & 1000 & 1.000 & 1000 & 1000 \\
\hline$Z P R$ & 1.000 & 1.000 & 1.000 & 1.000 \\
\hline
\end{tabular}

Tabel 4 di atas terlihat nilai composite reliability dari setiap variabel $>0,70$ dengan demikian dapat disimpulkan bahwa semua variabel mempunyai reabilitas yang baik

Goodness of Fit - Inner Model

Goodness of fit - inner model diukur menggunakan R-square variabel laten dependen dengan interpretasi yang sama dengan regresi; Q-Square predictive relevance untuk model konstruk, megukur seberapa baik nilai observasi dihasilkan oleh model dan juga estimasi parameternya.

Tabel 5. Nilai R Square

\begin{tabular}{|lr} 
& R Square \\
EOPO & 0.126 \\
CAR & 0.005 \\
FDR & 0.185 \\
NI & 0.060 \\
ROA & 0.090 \\
ZPR & 0.025
\end{tabular}

Tabel 5 di atas memberikan nilai 0,185 untuk konstruk Finance to Deposit Ratio (FDR), yang berarti bahwa intellectual capital mampu menjelaskan varians Finance to Deposit Ratio (FDR), sebesar 18,5 \%. Sedangkan memberikan nilai 0.005 untuk konstruk Capital Adequacy Ratio (CAR) yang berarti bahwa intellectual capital mampu menjelaskan varians Capital Adequacy Ratio (CAR) sebesar $0,5 \%$

Uji Kausalitas

\section{Gambar 1. Hasil Outer Model}




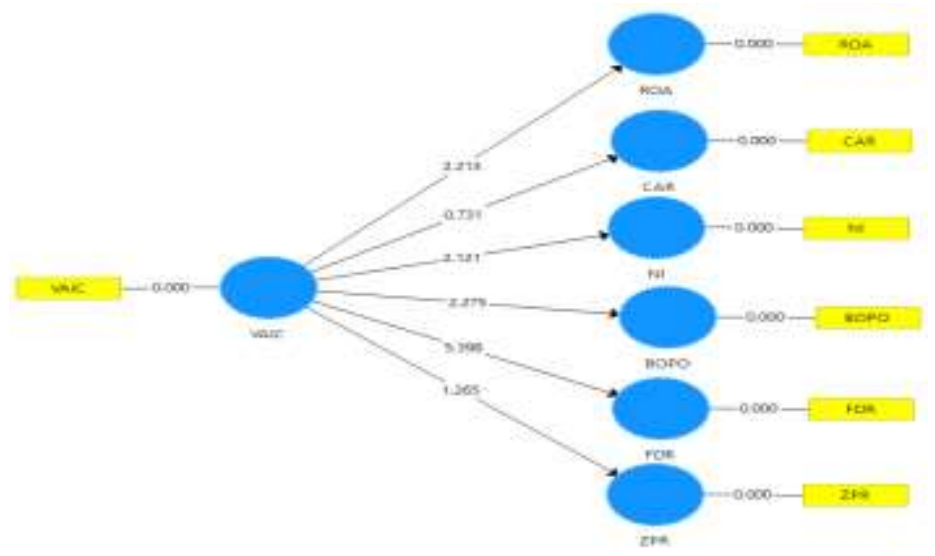

Hasil analisa PLS juga menghasilkan koefisien path sebagai berikut:

Tabel 6. Path Coefficients

\begin{tabular}{|l|r|r|r|r|} 
& Original Sample (O) & Sample Mean (M) & Standard Deviation (STDEV) & T Statistics (|O/STDEV|) \\
\hline VAIC $>$ BOPO & 0.356 & 0.414 & 0.156 & 2.275 \\
\hline VAIC $>$ CAR & -0.073 & -0.047 & 0.100 & 0.731 \\
\hline VAIC $>$ FDR & 0.430 & 0.473 & 0.080 & 5.398 \\
\hline VAIC $>$ NI & 0.245 & 0.285 & 0.116 & 2.121 \\
\hline VAIC $>$ ROA & -0.313 & -0.364 & 0.141 & 2.213 \\
\hline VAIC $>$ R ZRR & -0.159 & -0.133 & 0.126 & 1.265 \\
\hline
\end{tabular}

Tabel 6 menunjukkan bahwa intellectual capital mempunyai pengaruh yang signifikan terhadap Operating Expense to Operating Income (BOPO), hal ini terbukti dengan nilai t hitung sebesar 2.275. Dengan demikian hipotesis dalam penelitian ini yang menyatakan bahwa intellectual capital berpengaruh signifikan terhadap Operating Expense to Operating Income (BOPO) diterima.

Tabel 6 menunjukkan bahwa intellectual capital tidak mempunyai pengaruh yang signifikan terhadap Capital Adequancy Ratio (CAR), hal ini terbukti dengan nilai t hitung sebesar 0.731. Dengan demikian hipotesis dalam penelitian ini yang menyatakan bahwa intellectual capital tidak berpengaruh signifikan terhadap Capital Adequancy Ratio (CAR) ditolak.

Tabel 6 di atas dapat diketahui bahwa intellectual capital mempunyai pengaruh yang signifikan terhadap Finance to Deposit Ratio (FDR), hal ini terbukti dengan nilai $t$ hitung sebesar 5,398. Namun pengaruhnya bukan negatif melainkan positif, ini ditunjukkan oleh besarnya parameter bernilai positif yaitu 0,430 sehingga semakin tinggi intellectual capital maka semakin tinggi FDR. Dengan demikian hipotesis dalam penelitian ini yang menyatakan bahwa 
intellectual capital berpengaruh positif terhadap Finance to Deposit Ratio (FDR) diterima.

Tabel 6 menunjukkan bahwa intellectual capital mempunyai pengaruh yang signifikan terhadap Net Imbalan (NI), hal ini terbukti dengan nilai t hitung sebesar 2.121. Dengan demikian hipotesis dalam penelitian ini yang menyatakan bahwa intellectual capital berpengaruh signifikan terhadap Net Imbalan (NI) diterima.

Tabel 6 menunjukkan bahwa intellectual capital mempunyai pengaruh yang signifikan terhadap Return On Asset (ROA), hal ini terbukti dengan nilai t hitung sebesar 2.213. Dengan demikian hipotesis dalam penelitian ini yang menyatakan bahwa intellectual capital berpengaruh signifikan terhadap Return On Asset (ROA) diterima.

Tabel 6 menunjukkan bahwa intellectual capital tidak mempunyai pengaruh yang signifikan terhadap Zakat Performing Ratio (ZPR), hal ini terbukti dengan nilai t hitung sebesar 1.265. Dengan demikian hipotesis dalam penelitian ini yang menyatakan bahwa intellectual capital tidak berpengaruh signifikan terhadap Zakat Performing Ratio (ZPR) ditolak.

\section{Pembahasan}

\section{Pengaruh Intellectual Capital Terhadap Return On Asset (ROA)}

Hasil penelitian menunjukkan bahwa intellectual capital mempunyai pengaruh yang signifikan terhadap Return On Asset (ROA), hal ini terbukti dengan nilai t hitung sebesar 2.213. Dengan demikian hipotesis dalam penelitian ini yang menyatakan bahwa intellectual capital berpengaruh signifikan terhadap Return On Asset (ROA) diterima. Hasil ini sesuai dengan penelitian yang dilakukan oleh Ulum 2009 yang menyatakan bahwa intellectual capital berpengaruh terhadap kinerja keuangan perusahaan, dimana di dalam menghitung kinerja keuangan, Ulum juga menggunakan indikator ROA. Selain itu penelitian ini juga didukung oleh penelitian yang dilakukan oleh Erliana Banjarnahor 2019, namun berlawanan dengan penelitian yang dilakukan Edwin Wibisono 2019.

Ketika modal intelektual (human capital) perusahaan semakin tinggi, melalui pemanfaatan tenaga kerja secara maksimal dan optimal, misalnya seorang karyawan mempunyai keahlian dan kemampuan dalam menyelesaikan lebih dari satu tugas dibandingkan orang lain sehingga dapat meningkatkan kompetensi perusahaan. Indikasi lainnya adalah gaji dan tunjangan yang lebih besar kepada karyawan dapat memotivasi karyawan tersebut untuk 
meningkatkan produktivitasnya dalam proses operasional perbankan. Pengelolaan sumber daya manusia (SDM) yang baik dalam perusahaan dapat meningkatkan produktivitas karyawan yang nantinya juga akan meningkatkan pendapatan dan profit perusahaan Dengan kata lain, efisiensi penggunaan modal manusia dalam perusahaan perbankan merupakan faktor yang penting untuk meningkatkan kinerja keuangan. Hal tersebut akan mempengaruhi penilaian investor terhadap perusahaan-perusahaan perbankan, sehingga investor akan menilai bahwa perusahaan perbankan telah memperhatikan Human Capital Efficiency (HCE) dalam meningkatkan efisiensi total perusahaan.

Hasil penelitian ini juga menunjukkan semakin mampu perusahaan mengelola intellectual capitalnya akan memberikan nilai tambah bagi perusahaan. Selain itu, juga dapat dinilai bahwa efisiensi yang dapat dilakukan terhadap ketiga modal perusahaan sangat berkontribusi terhadap keseluruhan peningkatan kinerja perusahaan. Keadaan ini menunjukkan bahwa informasi ROA masih menjadi salah satu pedoman bagi para investor dalam menilai tingkat efisiensi yang dilakukan perusahaan dalam menghasilkan laba dan menjadikan salah satu pedoman bagi investor dalam melakukan kegiatan investasi atau keputusan lainnya. 9

\section{Pengaruh Intellectual Capital terhadap Capital Adequancy Ratio (CAR)}

Hasil penelitian menunjukkan bahwa intellectual capital tidak mempunyai pengaruh yang signifikan terhadap Capital Adequancy Ratio (CAR), hal ini terbukti dengan nilai t hitung sebesar 0.731. Dengan demikian hipotesis dalam penelitian ini yang menyatakan bahwa intellectual capital tidak berpengaruh signifikan terhadap Capital Adequancy Ratio (CAR) ditolak. Hasil penelitian ini bertentangan dengan penelitian yang dilakukan oleh Ike Kurniawati 2018.

Semakin tinggi modal intelektual yang diciptakan dari investasi perusahaan dalam sumber daya manusia, maka semakin tinggi pula permodalan perbankan. Semakin tinggi modal intelektual yang diciptakan dari investasi perusahaan pada aset fisik, maka semakin rendah permodalan perbankan karena banyak modal bank yang terpakai untuk membiayai aset fisiknya. Modal intelektual yang diciptakan dari investasi perusahaan dalam membangun struktur dan budaya perusahaan tidak berpengaruh terhadap permodalan perbankan yang berarti

${ }^{9}$ Erliana Banjarnahor, Analysis Ofvalue Added Intellectual Capitaltothe Financial Performance Of Listed Banking Companies In Indonesia (International Journal of Contemporary Accounting, Vol. 1 No. 1 July 2019), hal. 59-74. 
budaya dan struktur perbankan belum begitu baik dan belum bisa berpengaruh terhadap permodalan perbankan. 10

\section{Pengaruh Intellectual Capital terhadap Net Imbalan (NI)}

Hasil penelitian menunjukkan bahwa intellectual capital mempunyai pengaruh yang signifikan terhadap Net Imbalan (NI), hal ini terbukti dengan nilai t hitung sebesar 2.121. Dengan demikian hipotesis dalam penelitian ini yang menyatakan bahwa intellectual capital berpengaruh signifikan terhadap Net Imbalan (NI) diterima, Selain itu penelitian ini juga didukung oleh penelitian yang dilakukan oleh Gita Puspita (2019), namun berlawanan dengan penelitian yang dilakukan M. Dodik Suprayogi (2020). Semakin banyak transaksi perbankan juga mempengaruhi peningkatan pendapatan bank. Salah satu penyebab dari peningkatan ini adalah kenyamanan nasabah menggunakan fasilitas jasa yang diberikan oleh pihak perbankan. ${ }^{11}$

\section{Pengaruh Intellectual Capital terhadap Operating Expense to Operating Income (BOPO)}

Hasil penelitian menunjukkan bahwa intellectual capital mempunyai pengaruh yang signifikan terhadap Operating Expense to Operating Income (BOPO), hal ini terbukti dengan nilai t hitung sebesar 2.275. Dengan demikian hipotesis dalam penelitian ini yang menyatakan bahwa intellectual capital berpengaruh signifikan terhadap Operating Expense to Operating Income (BOPO) diterima. penelitian ini juga didukung oleh penelitian yang dilakukan oleh Siti Mardilia Farihah, Setiawan Setiawan (2020) bahwa IB-VAIC berpengaruh secara negatif dan signifikan terhadap kinerja keuangan. Hasil penelitian ini menunjukkan hubungan yang negatif, dalam arti bahwa semakin tinggi nilai intellectual capital maka semakin rendah nilai BOPO. Ketika intellectual capital meningkat, maka biaya operasional yang dikeluarkan oleh bank syariah menjadi

\footnotetext{
${ }^{10}$ Ike kurniawati, Pengaruh Intellectual Capital Terhadap Kinerja Keuangan (Studi Kasus : Perusahaan Perbankan yang Terdaftar di BI Tahun 2014-2017) (Surabaya : Universitas Wijaya Kusuma Surabaya, 2018), hal. 93

${ }^{11}$ M. Dodik Suprayogi, Pratiwi Dwi Karyati, Pengaruh Intellectual Capital Terhadap Kinerja Perusahaan Perbankan yang Terdaftar di Bursa Efek Indonesia (Universitas Wijaya Kusuma Surabaya, Vol. 01, No. 2, Januari 2020) hal. 19
} 
berkurang, sehingga lebih efisien. Hal ini berarti jika nilai intellectual capital meningkat, maka biaya operasional dapat diminimalisir. ${ }^{12}$

Pengaruh Intellectual Capital Terhadap Finance to Deposit Ratio (FDR)

Hasil penelitian menunjukkan bahwa intellectual capital mempunyai pengaruh yang signifikan terhadap Finance to Deposit Ratio (FDR), hal ini terbukti dengan nilai $\mathrm{t}$ hitung sebesar 5,398. Namun pengaruhnya bukan negatif melainkan positif, ini ditunjukkan oleh besarnya parameter bernilai positif yaitu 0,430 . Penelitian ini belawanan dengan hasil penelitian yang dilakukan Gita Puspita (2019) yang menyatakan bahwa penelitian ini menunjukkan bahwa VAIC tidak ada pengaruh signifikan pada FDR, yang berarti tidak terdapat pengaruh yang signifikan antara Intellectual Capital terhadap Liquidity.

Semakin tinggi FDR menunjukkan semakin riskan kondisi likuiditas bank, namun sebaliknya semakin rendah FDR menunjukkan kurangnya efektivitas bank dalam menyalurkan pembiayaan. Intellectual Capital yang dikelola secara efisien akan meningkatkan apresiasi nasabah terhadap kinerja bank syari'ah. Manajemen perbankan diharapkan dapat mengelola Intellectual Capital dengan strategi dan kebijakan yang tepat agar bank syari'ah mampu mengoptimalkan kinerja dan dapat bersaing dengan bank konvensional. Bank syari'ah akan dapat bersaing apabila menggunakan keunggulan kompetitif yang diperoleh melalui inovasi kreatif bank yang dihasilkan melalui komponen-komponen Intellectual Capital.

\section{Pengaruh Intellectual Capital terhadap Zakat Performing Ratio (ZPR)}

Hasil penelitian menunjukkan bahwa intellectual capital tidak mempunyai pengaruh yang signifikan terhadap Zakat Performing Ratio (ZPR), hal ini terbukti dengan nilai t hitung sebesar 1.265. Dengan demikian hipotesis dalam penelitian ini yang menyatakan bahwa intellectual capital tidak berpengaruh signifikan terhadap Zakat Performing Ratio (ZPR) ditolak. Penelitian ini sejalan dengan hasil penelitian yang dilakukan Dinda Abdita Siregar (2020). Hasil penelitian menunjukkan bahwa intellectual capital (VAIC) tidak berpengaruh terhadap kinerja bank syariah berdasarkan pendekatan Islami atau Islamicity Performance Indexterutama pada ZPR bank syariah baik itu secara parsial maupun secara

12 Siti Mardilia Farihah, Setiawan Setiawan, Determinan Intellectual Capital terhadap Profitabilitas di Bank Syariah:Pengujian Mediasi Kinerja Keuangan dan Kinerja Non Keuangan (Jurnal Samudra Ekonomi dan Bisnis Volume 11, Nomor 2, Juli 2020) hal .11 
simultan. Hal ini menunjukkan bahwa pengelolaan IC yang baik pada bank syariah tidak berpengaruh pada kinerja bank syariah beradasarkan pendekatan Islami yang dilihat dari penyaluran dana zakat yang dilakukan.

Zakat adalah salah satu tujuan utama dalam akuntansi Islam terutama zakat menjadi perintah dalam Islam. Oleh karena itu,pembayaran zakat adalah dasar untuk menganalisis kinerja bank syariah. Ini menggantikan indikator kinerja konvensional, yaitu laba per saham. Kekayaan bank harus didasarkan pada aset bersih daripada laba bersih yang ditekankan dengan metode konvensional. Karena itu, jika aset bank lebih tinggi, maka tentu saja ia juga akan membayar zakat tinggi.

\section{Kesimpulan}

1. Intellectual capital mempunyai pengaruh yang positif terhadap Return On Asset (ROA), hal ini terbukti dengan nilai t hitung sebesar 2.213.

2. Intellectual capital tidak mempunyai pengaruh yang signifikan terhadap Capital Adequancy Ratio (CAR), hal ini terbukti dengan nilai t hitung sebesar 0.731 .

3. Intellectual capital mempunyai pengaruh yang positif terhadap Net Imbalan (NI), hal ini terbukti dengan nilai t hitung sebesar 2.121.

4. Intellectual capital mempunyai pengaruh negatif terhadap Operating Expense to Operating Income (BOPO), hal ini terbukti dengan nilai t hitung sebesar 2.275 .

5. Intellectual capital mempunyai pengaruh positif terhadap Finance to Deposit Ratio (FDR), hal ini terbukti dengan nilai t hitung sebesar 5,398.

6. Intellectual capital tidak mempunyai pengaruh terhadap Zakat Performing Ratio (ZPR), hal ini terbukti dengan nilai t hitung sebesar 1.265.

\section{Daftar Pustaka}

Erliana Banjarnahor, 2019, Analysis Ofvalue Added Intellectual Capitaltothe Financial Performance of Listed Banking Companies In Indonesia, International Journal Of Contemporary Accounting, Vol. 1 No. 1 July , hal. 5974.

Halim Adi Gunawan, 2012, Pengukuran, Pengakuan dan Pengungkapan Intellectual capital Terhadap Penilaian Kinerja Perusahaan Jurnal Ilmiah Akuntansi, Vol. 1, No.3. h. 41

Ihyaul Ulum, 2009, Intellectual Capital, Yogyakarta: Graha Ilmu, h. 94 
Ihyaul Ulum, 2013,iB-VAIC: Model Pengukuran Kinerja Intellectual Capital Perbankan Syariah di Indonesia dalam Jurnal Inferensi 7 (1):183-204, h. 89.

Ike kurniawati, 2018 Tesis: Pengaruh Intellectual Capital Terhadap Kinerja Keuangan (Studi Kasus : Perusahaan Perbankan yang Terdaftar di BI Tahun 2014-2017), Surabaya , Universitas Wijaya Kusuma Surabaya hal. 93

Imam Ghozali, 2014, Structural Equation Modeling Metode Alternatif dengan Partial Least Square, Semarang, Badan Penerbit Universitas Diponegoro, h.20

Jumingan, 2006, Analisis Laporan Keuangan, Jakarta, PT Bumi Aksara, h. 239

Khoe Yao Tung, 2018, Memahami Knowledge Management, Jakarta Barat, Indeks, h.16.

M. Dodik Suprayogi, Pratiwi Dwi Karyati, 2020, Pengaruh Intellectual Capital Terhadap Kinerja Perusahaan Perbankan yang Terdaftar di Bursa Efek Indonesia, Universitas Wijaya Kusuma Surabaya, Vol. 01, No. 2, hal. 19

Martono dan Agus Harjiko,2015, Manajemen Keuangan, Yogyakarta,Ekonosia, h. 60

Siti Mardilia Farihah, Setiawan Setiawan, 2020, Determinan Intellectual Capitalterhadap Profitabilitas di Bank Syariah:Pengujian Mediasi Kinerja Keuangan dan Kinerja Non Keuangan", Jurnal Samudra Ekonomi dan Bisnis Volume 11, Nomor 2, hal .11

Werner R Murhadi, 2015, Analisis Laporan Keuangan Proyeksi dan Valuasi Saham, Jakarta, Salemba Empat, hal. 24. 